\title{
A U.K. perspective on Brexit Consideration of potential issues for academic and research libraries
}

$\mathrm{n}$ an historic referendum held June 23,

2016, to determine whether the United Kingdom (U.K.) should leave or remain as members of the European Union (EU), the British people voted $52 \%$ in favor of the U.K. withdrawing from its membership in the EU. As a plebiscite, arguably the result has validity as the proportion of those eligible to vote was high at $72 \%$, with more than 30 million voters in total. ${ }^{1}$

A formal announcement in March 2017 by the U.K. government launched the withdrawal process, due to conclude March 29, 2019. This scheduled departure of the U.K. from the EU is popularly referred to as "Brexit" from a contraction of the phrase "British exit from the European Union."

Negotiations for the U.K. withdrawal are governed by the terms of Article 50 of the 2009 Lisbon Treaty, which outlines a basic five-point plan for any country wishing to leave the $\mathrm{EU}$, including a time limit of two years on negotiations. However, as a leading EU legal expert observed: "The treaty said that you have two years within which to make your divorce settlement. But the divorce settlement is completely separate from the framework agreement for your future relations with the EU." ${ }^{2}$ In other words, there are two entirely separate processes: one governs the terms of the departure, while the second addresses future relationships between the U.K. and the remaining EU partners, subject to a separate round of negotiations.

Opinion differs on whether an agreement is necessary or even desirable. Essentially, there is a basic division, which can be cat- egorized as "Deal versus No Deal." One view holds that it is in the best interests of the U.K. to exit by the due date regardless of whether a withdrawal agreement is in place (No Deal), and the opposing view is that an agreement is fundamental for the future well-being of the country and its relations with the EU (Deal).

Since 2017, the U.K. government has been attempting to gain majority approval in the U.K. Parliament for a withdrawal agreement with the remaining members of the EU. As of the writing of this column (November 3, 2019), the U.K. Parliament has voted against or failed to ratify any of the proposed withdrawal agreements. The deadline for withdrawal has been extended three times and is presently January 31, 2020, with the option of the U.K. leaving earlier if the latest draft of the withdrawal agreement is ratified in advance of that date. Accompanying the withdrawal agreement is a political declaration, governing future relations between the U.K. and the remaining EU countries, revised in October 2019. ${ }^{3}$

Given this seeming impasse, a general election has been called for December 12, 2019, the first winter election to be held in the U.K. since 1923 and one which is likely to make new changes to the political landscape and arithmetic.

Judith Broady-Preston is CILIP president-elect, visiting professorial fellow at UCL-Qatar and professor emerita at Aberystwyth University, email: jbp@aber.ac.uk 


\section{Implications for academic and research libraries}

More detailed analyses addressing the impact of the above on specific issues such as open access, and the work of academic libraries were published in 2016-2017, but little subsequently. ${ }^{4}$ This may be attributable, at least in part, to the uncertainty surrounding Brexit. Without a clear agreement and timeline, planning is extremely difficult. Most organizations have a variety of contingency plans in place addressing a range of possible future scenarios, including universities, and by extension, their library services. While the immediate prospect of a No Deal exit has receded, most higher education organizations have in hand preparations for a variety of issues, ranging from information and data flows, continuity of research collaborations and projects, and the immigration status of staff and students, to the more prosaic stockpiling of everyday basics such as toilet rolls. Given the highly volatile climate and issues of commercial confidentiality, it is difficult to gain any real insight into details of these preparations across the sector. Individual universities are keeping their plans closely confidential as are sectoral bodies such as the Chartered Institute of Library and Information Professionals (CLIP) and the Society of College, National and University Libraries.

A September 2019 Universities UK (UUK) survey of the degree of preparedness of universities for a No-Deal Brexit reported that of the 75 respondents, 100\% acknowledged being prepared to some extent ranging from fully or very (52\%) to slightly (48\%), with over $75 \%$ very or extremely concerned about the negative impact on their organization of such a deal. ${ }^{5}$

One of the fundamental precepts of the $\mathrm{EU}$ is the free movement of goods and people within the community. The rights of U.K. nationals domiciled and working in other EU countries and vice versa is a key area of concern during the Brexit process. For the academic community, this has extensive repercussions. The future rights and status of academic and research staff, including their employment security, appears uncertain. The latest draft version of the withdrawal agreement which has yet to be ratified by Parliament covers the rights of EU citizens in the U.K. and British citizens in the EU. The U.K. government website offers guidance on this area but warns that this is subject to change and needs to be checked. ${ }^{6}$

Depending on their length of residency, EU nationals living and working in the U.K. need to apply for settled or presettled status to maintain the status quo, with a final deadline for registration of June 2021. While this appears to allow a comfortable margin, there is anecdotal evidence that applications are taking longer to process now than when the scheme was first introduced. This remains an issue of concern for staff and managers alike.

With regard to agreement on workers' rights, an internal U.K. government memo on the consequences of the present Brexit deal renegotiation removes the word adequate from the U.K.-EU Political Declaration to describe mechanisms for enforcing common social, environmental, and labor standards after Brexit, replacing it with appropriate. ${ }^{\text {? }}$

The EU Erasmus Programme, originally established in 1987, is a student exchange program allowing students to study at universities in other EU countries for set periods. Erasmus+, or Erasmus Plus, is the successor program combining all of EU's current schemes for education, training, youth and sport, begun in January 2014. Current estimates are that $53 \%$ of U.K. university students who learn abroad, do so via this scheme. ${ }^{8}$

According to the Royal Society, "The U.K. is one of the largest recipients of research funding in the EU. Over the period 2007-2013 the U.K. received $€ 8.8$ billion out of a total of $€ 107$ billion expenditure on research, development and innovation in EU Member States, associated and third countries. This represents the fourth largest share in the EU."

A U.K. government website offers guidance on the current and future status of all EU -funded schemes, including Erasmus+ and the research program, Horizon 2020, which 
is continually updated. ${ }^{10}$ Under the current terms of the withdrawal agreement, the U.K. would continue to participate in all programs funded by the current EU budget (2014-20). A No-Deal scenario would result in the U.K. leaving the EU budget and no longer guaranteed to receive future project funding.

UUK offers updates on these issues via its "Brexit FAQs" and a UUK Brexit webinar series, delivered on YouTube in conjunction with the U.K. Government Foreign and Commonwealth Office Science and Information Network. ${ }^{11}$

There is also the sensitive issue of the future of open borders, especially in relation to the island of Ireland. North-South cooperation and collaboration is a key tenet of the Good Friday Peace Agreement of 1998, and there are numerous examples of existing cross-border initiatives, such as a single electricity supply. For the library and information sector, colleagues from the North and South have a lengthy history of jointly working, which pre-dates the 1998 agreement, including an annual conference organized by a joint committee, with venues alternating between the South and the North on an agreed basis. The IFLA World Library and Information Congress 2020 is scheduled to be held in Dublin in August with some satellite events likely to be held across the existing border. The issue of borders and the potential impact of changes to the status quo lies at the heart of current difficulties in achieving consensus and approval for a withdrawal agreement within the U.K.

\section{Conclusion}

For U.K. universities, late 2019 is arguably a period of great uncertainty. The impact of such core issues as the constituency of the staff and student body, reliability and predictability of income streams, together with uncertainties surrounding the continuity of information and data flows and basic everyday essentials, means that contingency and scenario planning are critical skills. Effective communication with staff and students is crucial. Many universities are holding regular town hall meetings to brief on their preparations and allow individuals to ask questions, and perhaps as importantly, express concerns. Other support mechanisms include FAQs and designated information points or drop-in clinics.

From the library and information sector perspective in the U.K., the general election offers an opportunity to raise the profile of the sector in general, as well as address specific concerns arising from Brexit. CLIP U.K. has a 2019 general election campaign\#VoteLibraries-live from November 6, which runs through the general election period to December 12. CILIP U.K. has worked with the EveryLibrary Institute on the campaign, which mirrors their successful US-based \#VoteLibraries initiative. The stated aim of the \#VoteLibraries campaign is to ensure libraries, and particularly publicly funded libraries, are front-of-mind for candidates in the election, to ensure that they have positive attitudes towards the sector once a new Parliament and new government are formed. ${ }^{12}$

While this article is a personal perspective on the impact of Brexit on U.K. academic and research libraries, clearly there are also implications for libraries and their communities in the remaining EU countries. Furthermore, the Brexit process offers a salutary reminder of how geopolitical and economic agreements have global implications given the extent to which we are all connected technologically, culturally, and economically. Although the information resources provided are U.K.focused, nonetheless, the issues raised foreshadow concerns universally as well as globally for the free flow of information and collaboration among academic and research libraries worldwide.

\section{Notes}

1. "Brexit: All you need to know about the U.K. leaving the EU," October 29, 2019, https://www.bbc.com/news/uk -politics-32810887 (accessed October 31, 2019).

2. Tracy Ollerenshaw, "Article 50: The simplest explanation you'll find," BBC News, October 2, 2016, www.bbc.co.uk/newsbeat 
/article/36634702/article-50-the-simplest -explanation-youll-find (accessed October 31, 2019).

3. "New Withdrawal Agreement and Political Declaration," Policy Paper, GOV.UK, https:// www.gov.uk/government/publications /new-withdrawal-agreement-and-political -declaration (accessed October 31, 2019).

4. See for example: Paul Ayris, "Brexitand Its Potential Impact for Open Access in the UK," Insights 30 (1) (2017): 4-10, http:// doi.org/10.1629/uksg.336.

Erin Gow, "Brexit from the Reference desk: understanding and researching the British exit from the European Union," Faculty Scholarship (2017): 333, http://ir.library. louisville.edu/faculty/333.

Laurence Morris, "The Implications of Brexit for Libraries: An Academic Librarian's Perspective," December 23, 2016, https:// www.e-ir.info/2016/12/23/the-implications -of-brexit-for-libraries-an-academic-librarians -perspective/.

5. "Majority of universities well-prepared for no-deal Brexit; but continue to fear negative impact," September 16, 2019, Universities UK, https://www.universitiesuk.ac.uk/news /Pages/Majority-of-universities-well -prepared-for-no-deal-Brexit;-but-continue -to-fear-negative-impact.aspx (accessed November 1, 2019).

6. "Living in the EU: prepare for Brexit," Guidance, October 15, 2019, GOV.UK, https://www.gov.uk/guidance/living-in-the -eu-prepare-for-brexit (accessed November 2, 2019).
7. Faisal Islam, "Brexit negotiators removed 'adequate' from worker rights plan," BBC News, October 27, 2019, https://www. bbc.com/news/business-50199309 (accessed October 31, 2019).

8. "Erasmus: What will happen to scheme after Brexit?" BBC News, September 27, 2019, https://www.bbc.com/news /education-47293927 (accessed October 31, 2019).

9. "How much research funding does the UK get from the EU and how does this compare with other countries?" 2019, The Royal Society, https://royalsociety. org/topics-policy/projects/uk-research-and -european-union/role-of-EU-in-funding-UK -research/how-much-funding-does-uk-get-in -comparison-with-other-countries/ (accessed November 2, 2019).

10. "The government's guarantee for EU-funded programmes if there's no Brexit deal," Guidance, updated October 29, 2019, GOV.UK, https://www.gov.uk/government /publications/the-governments-guarantee -for-eu-funded-programmes-if-theres-no -brexit-deal/the-governments-guarantee-for -eu-funded-programmes-if-theres-no-brexit -deal\#planning-for-a-deal (accessed November 2, 2019).

11. "Brexit FAQs," Universities UK, https://www.universitiesuk.ac.uk/policyand-analysis/brexit/Pages/brexit-faqs.aspx (accessed November 2, 2019).

12. Nick Poole, unpublished email to the author, November 1, 2019. interest to our community. Both collaborations fit well with the library's strategic direction that focuses on fostering strategic partnerships and with the core value of community engagement. Through its efforts in promoting cultural competencies and its programming supporting inclusiveness, the library is positioned to be a leader in sup- porting an inclusive environment at VWU.

\section{Notes}

1. The full plan is available at: https:// sites.google.com/vwu.edu/hofheimer-library -plan-2018-2.

2. https://www.equalityvirginia.org/.

3. https://www.hrbigread.org/. n 